J. Clin. Chem. Clin. Biochem.

Vol. 26, 1988, pp. 559-568

(C) 1988 Walter de Gruyter \& Co.

Berlin - New York

\title{
Isolation of Immunoglobulins and Their Use in Immunoaffinity HPLC
}

\author{
By Dj. Josic, W. Hofmann, R. Habermann, J.-D. Schulzke and W. Reutter \\ Institut für Molekularbiologie und Biochemie, Freie Universität Berlin, Berlin (Dahlem), West Germany
}

(Received March 25/June 21, 1988)

Dedicated to Professor Heinz Tiedemann on his 65th birthday

Summary: For the isolation of monoclonal and polyclonal antibodies different high performance liquid chromatography (HPLC) and high performance affinity chromatography (HPAC) methods were investigated. Specially designed "mixed-bed" ion-exchange and hydroxylapatite columns as well as hydrophobic interaction columns were efficiently applied to the isolation of monoclonal antibodies. When these methods are used for the isolation of polyclonal antibodies from antiserum, the sample has to be pre-treated, e.g. by removal of serum albumin.

Protein A HPAC is an easy method and quick to handle, especially for the preparative isolation of antibodies. The antibodies that do not bind to protein A, can be purified by protein G HPAC. If this method cannot be used because of the rather extreme elution conditions, hydroxylapatite, ion-exchange or hydrophobic interaction HPLC have to be considered as alternatives.

We further concentrate on immunoaffinity HPLC with immobilized antibodies. This method has proved to be very effective for one-step isolation of antigens, even from very complex samples such as plasma membrane extracts. The problem with immunoaffinity HPLC is the quick deterioration of the columns, caused by increasing denaturing of the immobilized antibodies during elution. In order to solve this problem, an indirect method is recommended for analytical immunoaffinity HPLC. For this purpose, the antibodies are bound to a protein A HPAC column. The solution containing the antigens is then applied. After washing, the antigenantibody complex is eluted from the column.

\section{Introduction}

The pioneering investigations of Köhler \& Milstein (1) have enabled the experimental production of monoclonal antibodies. By improved methods of protein isolation, among them several HPLC methods, it has become much easier to isolate single proteins, as well as to raise monoclonal and polyclonal antibodies against them. Special HPLC methods have been designed, which allow selective separation of immunoglobulins from antiserum or ascites fluid or cell culture supernatants. Using these methods, especially affinity HPLC (HPAC), the antibody can be enriched and highly purified from hundreds of milliliters of a solution (2-4).
For several years we have been isolating antibodies by using different HPLC and HPAC methods. The isolated antibodies are immobilized to different supports in order to isolate chosen antigens in a single step from complex solutions such as serum and plasma membrane extracts. The results are compiled in this paper.

\section{Materials and Methods}

Chemicals and radioactively labelled compounds

All chemicals were of analytical grade and purchased from $E$. Merck AG (Darmstadt, F. R. G.) or Sigma (St. Louis, U. S. A.). $L-\left[{ }^{35} S\right] M e t h i o n i n e(38.4 \mathrm{PBq} / \mathrm{mol})$ was obtained from the Radiochenical Centre (Amersham, Bucks., England). 


\section{Antibodies}

Monoclonal antibodies were produced essentially according to the method of Köhler \& Milstein (1). A modified method for the preparation of monoclonal antibodies against rat liver membrane proteins has been described elsewhere (5). Polyclonal antibodies against rat transferrin were purchased from Cappel (Cochranville, PA., U.S. A.). Other polyclonal antibodies were raised either in rabbits or in goats against purified proteins. Twenty micrograms of purified protein were emulsified in Freund's adjuvant and injected intradermally. At ten-day intervals animals received booster injections of $30 \mu \mathrm{g}$ of antigen in Freund's incomplete adjuvant. Serum was collected 10 days after the third inoculation.

\section{Labelling of proteins in vivo}

Male Wistar rats $(120-130 \mathrm{~g})$ were intravenously injected with $92.5 \mathrm{MBq}$ of $L-\left[{ }^{35} \mathrm{~S}\right]$ methionine (specific radioactivity $38.4 \mathrm{PBq} /$ mol) per $\mathrm{kg}$ body weight. Three hours later the animals were killed, and livers were perfused with $40 \mathrm{ml}$ of saline. Serum was collected and plasma membranes were prepared from the pooled livers of five rats. The isolation and selective extraction of plasma membranes have been described elsewhere $(6,7)$.

\section{Determination of radioactivity}

Protein-bound radioactivity of serum and plasma membranes was determined by the method of Mans \& Novelli (8) modified by Bauer et al. (9). For quantification of transferrin-bound radioactivity, a $100 \mu \mathrm{l}$ aliquot was counted in $10 \mathrm{ml}$ of Unisolve 1 scintillator (Koch Light) in a Kontron liquid scintillation system MR 300 DPM (Kontron Analytik, München, F. R. G.) with automatic quench correction and a counting efficiency of $75-80 \%$ as determined by external standard and channels ratio method. Protein was determined by the method of Lowry et al. (10).

\section{SDS-PAGE}

SDS-PAGE was carried out according to the Laemmli method (11). Fluorographic analysis of gels was done according to Bonner \& Laskey (12), using Kodak XAR-5 film.

\section{HPLC}

The HPLC system consisted of two pumps (Bischoff Analysentechnik, Leonberg, F. R.G.), a programmer (C-R 3A, Shimadzu-Bischoff Analysentechnik), a spectral photometer with a deuterium lamp (Bischoff), a RH 7125 loop injection valve (Bischoff) and a Frac-100 fraction collector (Pharmacia-LKB, Freiburg/Br., F.R.G.). The chromatographic conditions are given in the figure legends.

\section{Columns and supports}

The activated supports used for coupling of affinity ligands were as follows: Eupergit $\mathrm{C} 1 \mathrm{Z}, 1 \mu \mathrm{m}$ particle size, without pores; Eupergit $C 30 \mathrm{~N}$, particle size $30 \mu \mathrm{m}$ and pore size about $50 \mathrm{~nm}$. Both are based on a polymer and have an epoxy or tresyl radical as active group (Röhm Pharma GmbH, Weiterstadt, F.R.G.). Activated 3-isothiocyanate propyl triethoxy silan-modified silica, particle size $10 \mu \mathrm{m}$, pore size $50 \mathrm{~nm}$, was a gift from Dr. $K$. K. Unger (Universität Mainz, F. R. G.). Cyanogen bromide-activated, polymer-based TSK 5PW gels, particle size $10 \mu \mathrm{m}$ and pore size $100 \mathrm{~nm}$ (first gel), particle size $2.5 \mu \mathrm{m}$ and non-porous (second gel), were from Toyohaas Co. (Yamaguchi, Japan). Tresyl activated silica, $10 \mu \mathrm{m}$ particle size and $50 \mathrm{~nm}$ pore size, was a gift from Dr. S. Ohlson (Perstrop Biolytica, Lund, Sweden).
The ligands, protein A (Pharmacia-LKB), protein G (Perstorp Biolytica) and antibodies were coupled according to the following procedure. Activated resin was first washed twice with binding buffer containing $0.1 \mathrm{~mol} / 1$ sodium carbonate, $\mathrm{pH} 8.0$, and $0.5 \mathrm{~mol} / \mathrm{l}$ sodium chloride. If the resin was silica-based, the $\mathrm{pH}$ of the binding buffer was adjusted to 7.2. The ligand, dissolved in binding buffer (protein $0.5^{\prime}-5 \mathrm{~g} / \mathrm{l}$ ), was added after centrifugation at $1000 \mathrm{~g}$ for $20 \mathrm{~min}$ at $+4^{\circ} \mathrm{C}$. The quantity of bound ligand was calculated from the amount of protein before and after coupling. In order to block the remaining active groups of the support, $10 \mathrm{ml}$ of $0.2 \mathrm{~mol} / \mathrm{l}$ ethanolamine hydrochloride, $\mathrm{pH} 7.0$, was added per $1 \mathrm{~g}$ of resin. The suspension was shaken at room temperature for $2 \mathrm{~h}$, centrifuged at $1000 \mathrm{~g}$ for $20 \mathrm{~min}$ and washed three times with binding buffer as described above. The gel with the immobilized ligand was stored at $+4{ }^{\circ} \mathrm{C}$ in phosphate-buffered saline, $\mathrm{pH} 7.0$, containing $1 \mathrm{~g} / 1$ of sodium azide, until required for column packing.

The columns were packed in our laboratory, except for the Eupergit $\mathrm{C} 1 \mathrm{Z}$ columns, which were packed by Bischoff Analysentechnik.

An alternative to the method described above is to bind the ligands to a column that has already been packed with activated support. For this purpose a Microanalyzer Succinylimide column (Bio Rad, München, F.R.G.), or Tresyl Silica column (Perstorp Biolytica) was used. The Succinylimide column is packed with a succinylimide activated polymer (cf. l.c. (13)), $40 \times 4.6 \mathrm{~mm}$, particle size $30 \mu \mathrm{m}$. The Tresyl-Silica column was packed in our laboratory, the column size being $40 \times 4.6 \mathrm{~mm}$ or $20 \times 4.6 \mathrm{~mm}$. The "in situ" binding of the ligand, in this case a monoclonal antibody, was carried out as follows. When a Succinylimide column was used, a solution of ligand (5-50 $\mathrm{mg}$ of protein per $1 \mathrm{~g}$ of support) in the binding buffer was recirculated within $2 \mathrm{~h}$ (flow rate $0.2 \mathrm{ml} / \mathrm{min}$ ). In the case of the Tresyl-Silica column a single injection of ligand was sufficient, no recirculation being required.

The column was washed with $50 \mathrm{ml}$ of binding buffer at a flow rate of $1 \mathrm{ml} / \mathrm{min}$. The flow rate was subsequently reduced to $0.4 \mathrm{ml} / \mathrm{min}$, and $2 \mathrm{ml}$ of $0.2 \mathrm{~mol} / \mathrm{l}$ ethanolamine hydrochloride, $\mathrm{pH} 7.0$, was injected twice. The column was then washed with $20 \mathrm{ml}$ of binding buffer and $20 \mathrm{ml}$ of tris buffered saline, $\mathrm{pH}$ 7.2 , at a flow rate of $1 \mathrm{ml} / \mathrm{min}$. The quantities of the bound antibodies were determined by the difference in protein content before and after coupling.

The pre-packed columns, Microanalyzer Protein A, $40 \times 4.6$ $\mathrm{mm}$, particle size $30 \mu \mathrm{m}$, was obtained from Bio Rad; the TSK Protein A 5PW column, $60 \times 4.6 \mathrm{~mm}$, particle size $10 \mu \mathrm{m}$, was a gift from Dr. Kato (Toyohaas Co.).

Columns for ion-exchange-HPLC were SynChropak AX-300, column size $250 \times 4.6 \mathrm{~mm}$, particle size $6 \mu \mathrm{m}$ (Bischoff Analysentechnik), an anion-exchanger; Mono S, $50 \times 5.0 \mathrm{~mm}$ column size and $10 \mu \mathrm{m}$ particle size, a cation-exchanger (Pharmacia-LKB); and Bakerbond ABx, a "mixed-bed" ion-exchange column, specially designed for antibody isolation, 100 $\times 7.75 \mathrm{~mm}$ column size, $5 \mu \mathrm{m}$ particle size, and $30 \mathrm{~nm}$ pore size, with a $40 \times 4.6 \mathrm{~mm}$ pre-column (Baker Chemikalien, Groß-Gerau, F. R. G.).

Columns for hydroxylapatite HPLC (HA-HPLC) were Pentax, $100 \times 8.0 \mathrm{~mm}$ column size, $10 \mu \mathrm{m}$ or $5 \mu \mathrm{m}$ particle size (Pentax Co., Hamburg, F. R. G.); TSK-Gel HA-1000, $80 \times 8.0 \mathrm{~mm}, 10$ $\mu \mathrm{m}$ particle size and $100 \mathrm{~nm}$ pore size (Toyohaas Co.), both columns packed with spherical particles; Bio-Gel HPHT column, $100 \times 7.8 \mathrm{~mm}$ column size, packed with irregularly shaped particles (Bio Rad). Each column was used with a $40 \times 4.6 \mathrm{~mm}$ pre-column, packed in our laboratory with 30 $\mu \mathrm{m}$ particle size hydroxylapatite (Pentax).

For hydrophobic interaction (HI)-HPLC a Eupergit C 30NDiol column was used, $120 \times 8.0 \mathrm{~mm}$ column size, $30 \mu \mathrm{m}$ particle size and about $50 \mathrm{~nm}$ pore size (Röhm Pharma $\mathrm{GmbH}$ ). 


\section{Buffers}

The buffers used for protein A- and protein G-HPAC and immunoaffinity (IA)-HPLC were:

Buffer $\mathrm{A}, 0.2 \mathrm{~mol} / 1$ sodium carbonatc, $\mathrm{pH} 8.2$, or $\mathrm{pH} 7.2$ if silica-based supports were used. Elution buffer, $0.1 \mathrm{~mol} / 1$ sodium citrate, $\mathrm{pH} 2.5$ or $3 \mathrm{~mol} / \mathrm{l}$ sodium thiocyanatc, $\mathrm{pH} 7.0$. For IA-HPLC of membranc protcins an amount of $1 \mathrm{~g} / \mathrm{l}$ detergent was added to the buffers according to sample solubility, either Genapol X 100, or CHAPS, or sulphobetainc. As washing buffer, buffer $A$ with $1 \mathrm{~g} / \mathrm{l}$ Genapol X 100 was used.

The buffers for IE-HPLC were buffer A, $10 \mathrm{mmol} / 1$ sodium 2morpholinocthancsulphonate (MES), pH 6.0; buffer B, 500 $\mathrm{mmol} / \mathrm{l}$ sodium phosphate, $\mathrm{pH} 6.8$.

The buffers for HA-HPLC were buffer $A, 22 \mathrm{mmol} / 1$ sodium phosphatc, pH 6.8 and buffor $B, 500 \mathrm{mmol} / 1$ sodium phosphate, pH 6.8.

The buffers for HI-HPLC were buffer $A, 1.7$ or $1.2 \mathrm{mmol} / \mathrm{l}$ ammonium sulphate in $0.1 \mathrm{mmol} / \mathrm{l}$ sodium phosphate, $\mathrm{pH} 7.0$, buffer $\mathrm{B}, 0.1 \mathrm{mmol} / \mathrm{l}$ sodium phosphate, $\mathrm{pH}$ 7.0.

\section{Sample preparation}

For antibody isolation, antiserum and ascites fluid were diluted with buffer $A$ at least five times. In the cases of IE-, HA- and HI-HPLC the sample and buffer A should have identical ionic strengths and $\mathrm{pH}$. This can be achicved either by dialysing against buffer A overnight or by suitable dilution of the sample. In the casc of HA-HPLC the fibrinogen is removed from the serum and the ascites fluid by adding calcium up to a concentration of $1 \mathrm{mmol} / \mathrm{l}$. The sample is left standing for $6 \mathrm{~h}$ at $+4^{\circ} \mathrm{C}$ after calcium chloride has been added. It is subsequently diluted to a ratio of $1: 7$ with $1 \mathrm{mmol} / \mathrm{l}$ sodium phosphatc buffer, pH 6.0, and centrifuged for $20 \mathrm{~min}$ at $100000 \mathrm{~g}$ (Kontron L Ultrazentrifuge). The pH of the sample should be 6.8 and is to be adjusted with $0.1 \mathrm{mmol} / 1$ hydrochloric acid.

The albumin is removed from the samples by chromatography on an affi-blue-gcl column (Bio Rad) (14).

\section{Results and Discussion}

\section{Ion-exchange HPLC}

Ion-exchange was one of the first HPLC methods of antibody purification. Anion-exchange as well as cation-exchange HPLC was used for the isolation of both monoclonal and polyclonal antibodies $(14,15)$. A problem that arises with the use of ion-exchange HPLC is the dissimilar behaviour of different antibodies, including monoclonal ones, in chromatographic runs, even under identical conditions. Consequently they have to be optimized for each antibody, especially for polyclonal antibodies. Different immunoglobulins, even different sub-classes of immunoglobulins, frequently appear as different peaks. Because of the large variety of proteins in the scrum, it is difficult to isolate all existing immunoglobulins as separate peaks. Therefore it is recommended that the serum albumin be first removed by affinity chromatography on an affi-blue column (sec Materials and Methods, and 1.c. (14)). As a result, a major portion of the protein is removed, overloading of the column is avoided, and separation conditions are much more favourable. As a routine method for the purification of both monoclonal and polyclonal antibodies, ionexchange HPLC is already obsolete. The above-mentioned effort for the optimization of separation is chiefly responsible for this. However, as ion-exchange HPLC has generally become a routine method for protein analysis in almost every laboratory, the use of the available ion-exchange HPLC columns for occasional antibody purifications does not require any additional resources. If a large amount of antibodies is needed, or if a variety of different monoclonal antibodies have to be routinely isolated, it is advisable to use ion-exchange columns that have been designed especially for this purpose. The $\mathrm{ABx}$ ion-exchange column is packed with a combination of an ionexchange and cation-exchange resins ("mixed-bed" column, see I.c. $(15,16))$. An example of an isolation of monoclonal antibodies from ascites fluid on an $\mathrm{ABx}$ column is shown in figure 1 . In the chromatographic run a large part of the protein was not retarded at all by the column. The immunoglobulin was then separated by a salt gradient from a small amount of other proteins that were being retarded by the column. The important advantage of an isolation

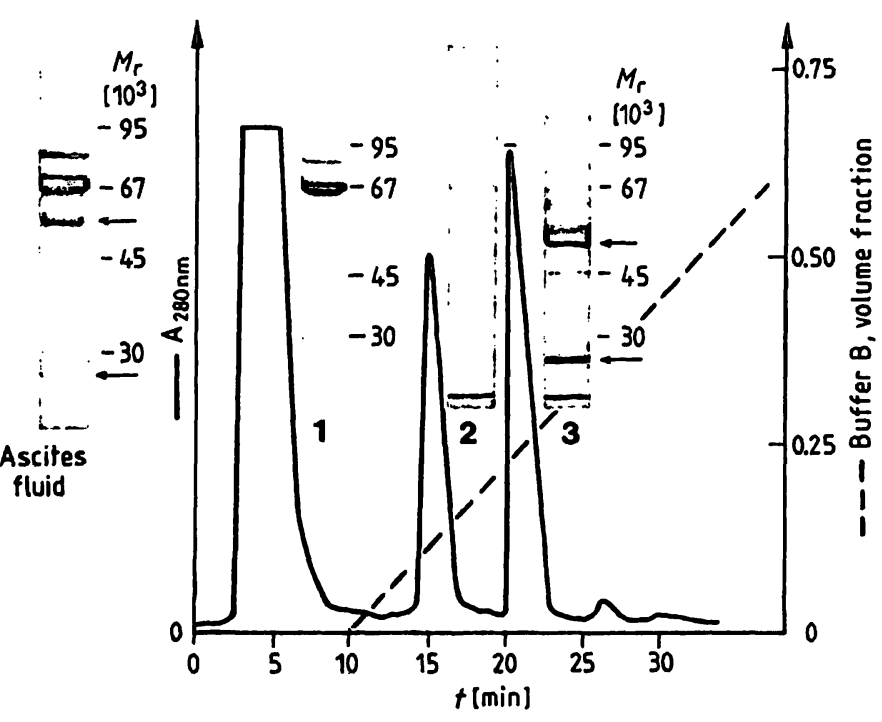

Fig. 1. Isolation of monoclonal antibodics from ascites Muid on an $\mathrm{ABx}$ "mixed-bed" column, $100 \times 7.75 \mathrm{~mm}$. One $\mathrm{ml}$ of ascites fluid was diluted in $4 \mathrm{ml}$ of buffer $A$ and dialysed overnight against buffer $A$. Conditions, $1 \mathrm{ml} /$ min flow rate, 40 bar pressure, room temperaturc. For other data cf. Matcrials and Methods. Fractions of $1 \mathrm{ml}$ each were collected, and aliquots of $20 \mu \mathrm{l}$ cach wore taken at the peaks for SDS-PAGE. Before HPLC scparation, $2 \mu$ l of the sample werc taken for SDS-PAGE. The eluted proteins are represented electrophoretically beside cach peak. The electrophoretical analysis of the sample is shown to the left of the chromatogram ("ascites fluid"). The heavy chain and the light chain of the IgG are marked with arrows. 
method like this lies in its very mild separation conditions, the immunoglobulins being eluted by $0.1-$ $0.2 \mathrm{~mol} / \mathrm{l}$ phosphate buffer, $\mathrm{pH}$ 6.8. The antibody solution can therefore be directly used for other purposes, e.g. be immobilized to activated supports.

\section{Hydroxylapatite HPLC}

Recently the hydroxylapatite matrix has been successfully produced for application in high performance liquid chromatography $(15,17)$. The behaviour of a hydroxylapatite column is shown in figure 2 . If a mixture of standard proteins is applied in a 1.0 $\mathrm{mmol} / \mathrm{l}$ sodium phosphate buffer, $\mathrm{pH} 6.8$, all the applied proteins, serum albumin, transferrin and $\mathrm{IgG}$, are retarded and can be eluted with a salt gradient of phosphate ( $1 \mathrm{mmol} / \mathrm{l}$ to $500 \mathrm{mmol} / \mathrm{l}$, part "a" of figure 2). Similar chromatograms are usually provided with pre-packed columns as a quality control. However, if the concentration of buffer $A$ is increased to 22 $\mathrm{mmol} / \mathrm{l}$ sodium phosphate, serum albumin and transferrin are practically not retarded at all by the column, whereas the IgG shows little change in its behaviour and is eluted only at a higher phosphate concentration (see part " $b$ " of figure 2). The standard proteins used here are also the main components of an ascites fluid. The isolation of monoclonal antibodies can therefore be carried out under the same chromatographic conditions as those dealt with in figure $2 \mathrm{~b}$. For this an appropriate sample preparation is required (cf. Materials and Methods). The sample volume is practically unlimited, because the immunoglobulins, not the remaining contaminating proteins, bind rather strongly to the column. Therefore this method is well suited for preparative isolation of monoclonal antibodies. Two examples of antibody purification are shown in figure 3. After establishing optimal separation conditions, major amounts, namely about 100 $\mathrm{mg}$, of monoclonal antibodies could be isolated from $15 \mathrm{ml}$ of ascites through a preparative column (250 $\times 20 \mathrm{~mm}$ ). The antibodies could be used without any further treatment for immobilization to corresponding supports (see below).

A shortcoming of hydroxylapatite chromatography is the relative water solubility of the matrix that can lead to a very short life of the column. In order to avoid such contingencies some authors recommend the addition of between 0.1 and $1 \mathrm{mmol} / 1$ calcium chloride to the buffers (17). We found in our experiments that this measure is unnecessary, when a precolumn is used for protection. Any pre-column, however, should be routinely replaced after about 30 runs. When suitable materials are at hand, the pre-column can be packed by the user himself without difficulty.
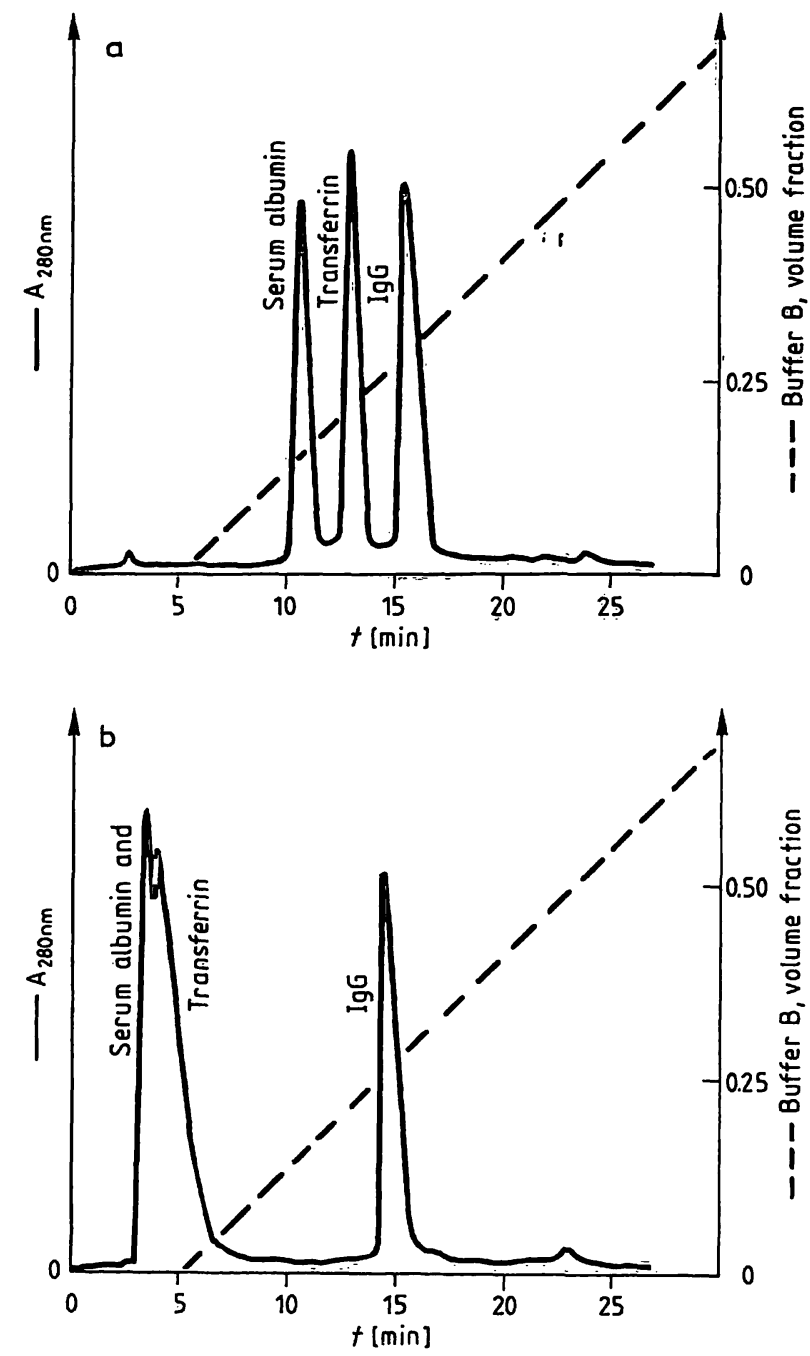

Fig. 2. Separation of standard proteins on a hydroxylapatite column, $1 \mathrm{mg}$ each of serum albumin, transferrin and immunoglobulin G. Conditions: $1 \mathrm{ml} / \mathrm{min}$ flow rate, Pentax column, $100 \times 8.0 \mathrm{~mm}, 5 \mu \mathrm{m}$ particle size, 15 bar pressure, room temperature, gradient as shown in the fig. 2 a) buffer $A-1 \mathrm{mmol} / \mathrm{l}$ sodium phosphate, $\mathrm{pH} 6.8$; b) buffer $\mathrm{A}-22 \mathrm{mmol} / 1$ sodium phosphate, pH 6.8. For other data see Materials and Methods.

With these precautions, a single hydroxylapatite HPLC column could be used for antibody isolation over 400 times.

\section{Hydrophobic interaction HPLC}

This method has seldom been used for the isolation of immunoglobulins. However, it provides a most welcome extension of existing methods, especially for the isolation of polyclonal antibodies. The Eupergit C 30N Diol resin (cf. fig. 4) is a support with a weakly hydrophobic surface. Ammonium sulphate was added to the pre-conditioned, crystalline antiserum, to a concentration of $1.2 \mathrm{~mol} / \mathrm{l}$. Under these conditions most serum proteins are either excluded or eluted at the beginning of the salt gradient. T The immunoglobulins, however, are retarded on the column and eluted 


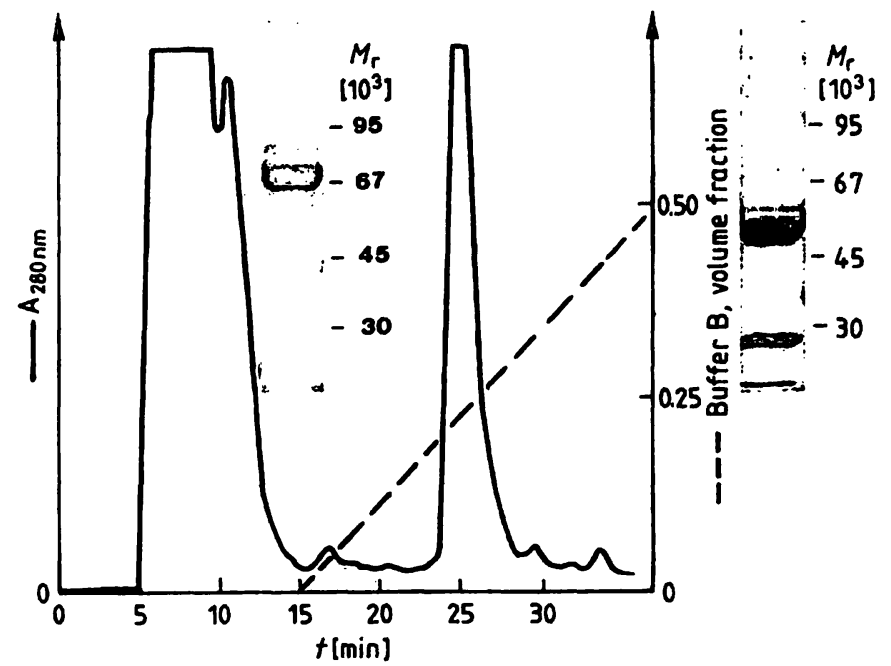

Fig. 3. Isolation of monoclonal antibodies on a preparative hydroxylapatite column. Fifteen $\mathrm{ml}$ of ascites fluid were diluted with $1 \mathrm{mmol} / 1$ phosphate buffer to $105 \mathrm{ml}$, and the $\mathrm{pH}$ was adjusted to 6.8 with $\mathrm{HCl}$. Separation was performed on a Pentax HA column, $250 \times 20 \mathrm{~mm}, 40$ $\mu \mathrm{m}$ particle size. Conditions, buffer A $-22 \mathrm{mmol} / \mathrm{l}$ sodium phosphate, buffer B - $500 \mathrm{mmol} / \mathrm{l}$ sodium phosphate, both $\mathrm{pH} 6.8 ; 10 \mathrm{ml} / \mathrm{min}$ flow rate, $10 \mathrm{bar}$ pressure, room temperature. The gradient is shown in the figure; a $60 \times 8.0 \mathrm{~mm}$ pre-column was used. Fractions of $10 \mathrm{ml}$ were collected and $20 \mu \mathrm{l}$ aliquots taken for SDS-PAGE. SDS-PAGE of the eluted proteins is shown beside each peak. For other data see materials and methods.

at a lower salt concentration. Other serum proteins, which are strongly retarded, e.g. fibronectin and ferritin, are eluted as separate peaks at a much lower salt concentration. The prepurification step, in which the antibodies are enriched through ammonium sulphate precipitation from the antiserum, improves column performance and capacity.

The advantage of hydrophobic interaction HPLC lies in the mild separation conditions, similar to those of ion-exchange HPLC. The small number of experiments reported so far suggest that this method can be applied very successfully to the isolation of antibodies, and it can be recommended (18).

\section{Affinity chromatographic methods}

Affinity chromatography is carried out by applying a sample that contains immunoglobulin to a HPAC column with an immobilized immunoglobulin-binding protein, e.g. protein $A$, protein $G$ or others. Thus only the immunoglobulins are retarded. The other proteins are separated and do not bind to the column. This procedure provides ideal conditions for antibody purification. This is shown in figure 5. Polyclonal antibodies against a membrane-bound glycoprotein

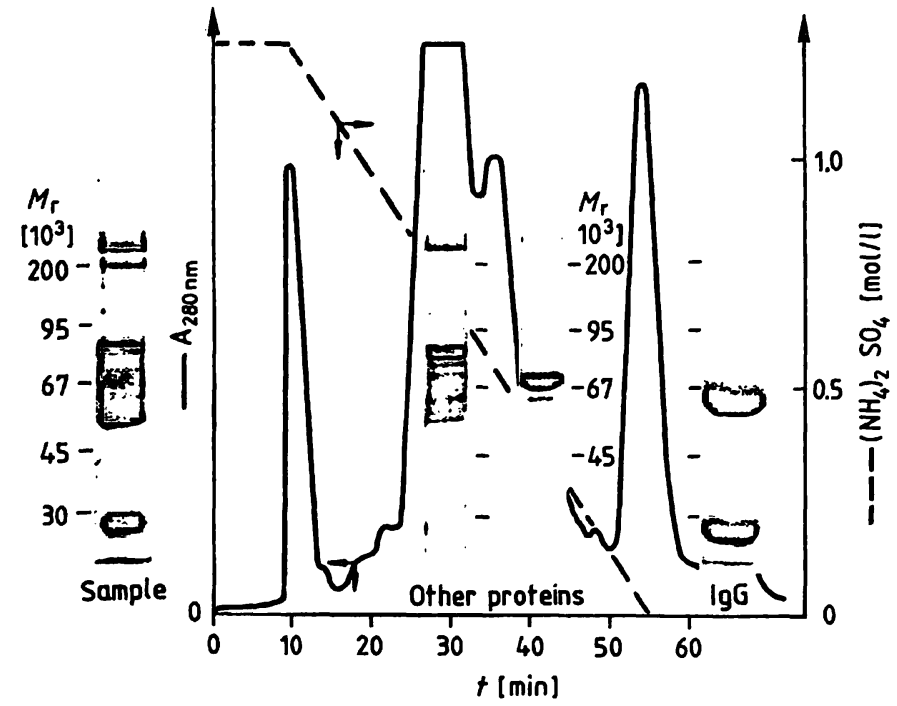

Fig. 4. Isolation of polyclonal antibodies from goat antiserum with hydrophobic interaction HPLC. A part of the proteins was removed from the sample by precipitation with ammonium sulphate. The pellet (about $50 \mathrm{mg}$ of protein) was mixed with $10 \mathrm{ml}$ of doubly distilled water, and dialysed overnight against $0.1 \mathrm{~mol} / 1$ sodium phosphate, $\mathrm{pH}$ 7.0. Before applying the sample, the ammonium sulphate concentration was adjusted to $1.2 \mathrm{~mol} / \mathrm{l}$ with crystalline ammonium sulphate. Conditions, Eupergit-Diol C $30 \mathrm{~N}$ column, $250 \times 8.0 \mathrm{~mm}, 1 \mathrm{ml} / \mathrm{min}$ flow rate, 3 bar pressure, room temperature. The gradient, as ammonium sulphate concentration, is shown in the figures. Fractions of $1 \mathrm{ml}$ were collected, and 20 $\mu l$ aliquots were taken for SDS-PAGE. SDS-PAGE of the sample (pellet after ammonium sulphate precipitation) before hydrophobic interaction HPLC is shown on the left, beside the chromatogram ("sample"). The last peak is more than $90 \%$ pure IgG (see SDS-PAGE).

were isolated from rabbit antiserum. Most reports on affinity chromatography deal with protein AHPAC $(2-4)$. However, some antibodies do not bind to protein $\mathrm{A}$. In order to find a way around this difficulty, special buffers are recommended for application of the sample to the protein A column. But such buffers are effective only in some cases, e. g. with rat IgG (2). Some mouse IgG sub-classes, among the monoclonal mouse antibodies, as well as certain goat antibodies, do not bind well to the protein $\mathrm{A}$. In the case of monoclonal antibodies obtained from ascites fluid, the above-mentioned methods of ion-exchange HPLC with ABx columns or hydroxylapatite HPLC can be considered as alternatives. As to antibodies from cell supernatants and antisera, hydrophobic interaction HPLC is the most favourable and simplest method for those that do not bind to protein $\mathrm{A}$.

Apart from protein A, there are other bacterial proteins which bind immunoglobulins. Of these, protein $G$ (19) and similar proteins (20) have been investigated. Protein $G$ binds mouse IgG sub-classes, which do not bind to protein A, and also goat IgG (not 


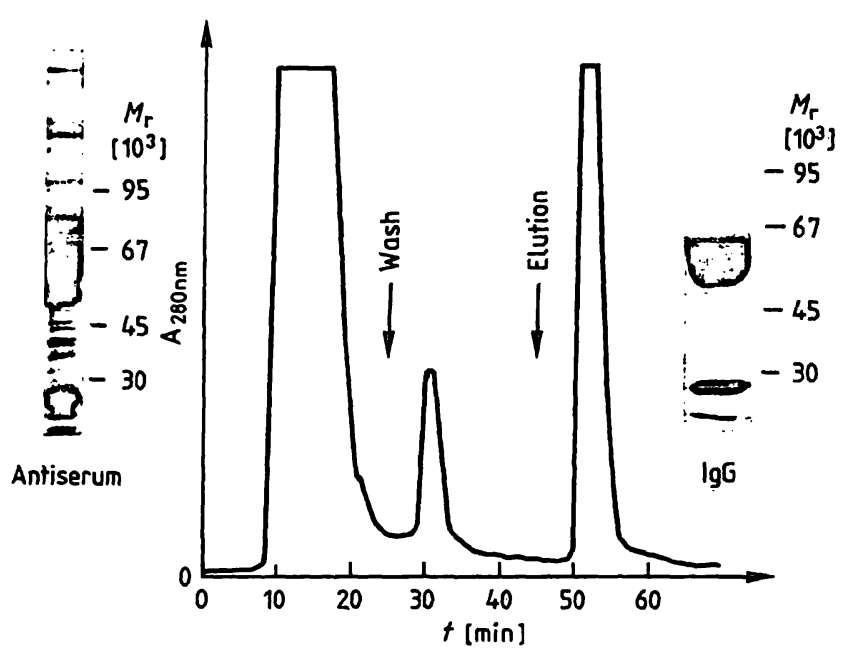

Fig. 5. Isolation of polyclonal antibodies from rabbit antiserum with protein A-HPAC. A part of the albumin was removed from the antiserum by chromatography on an affi-blue column (see materials and methods). The material that was not retarded on the affi-blue column (about $20 \mathrm{ml}$ ), was applied to a $80 \times 8.0 \mathrm{~mm}$ protein A Eupergit C $30 \mathrm{~N}$ column. The column was washed with $10 \mathrm{ml}$ of sodium borate buffer, $\mathrm{pH} 8.3$, with $1 \mathrm{~g} / \mathrm{l}$ non-ionic detergent Genapol X 100, in order to remove the non-specifically bound proteins ("wash"). The IgG was eluted with $0.1 \mathrm{~mol} / \mathrm{l}$ sodium citrate buffer, $\mathrm{pH} 2.4$. Other chromatographic conditions, $1.0 \mathrm{ml} / \mathrm{min}$ flow rate, 5 bar pressure, room temperature. The purity of the isolated IgG was monitored with SDS-PAGE ("IgG" in the figure). SDS-PAGE of the sample before separation is shown in the left part of the figure ("antiserum").

shown here). According to the results obtained in our preliminary experiments, neither protein A nor protein $\mathrm{G}$ binds immunoglobulin $\mathrm{M}$. This antibody therefore has to be isolated by other methods, e.g. ionexchange HPLC on the ABx column (15).

The binding between antibodies and protein $\mathrm{A}$ or protein $G$ is rather strong and antibodies can be eluted from the column either by buffers with a $\mathrm{pH}$ below 3 or by chaotropic reagents, such as $3 \mathrm{mmol} / \mathrm{l}$ sodium thiocyanate. The majority of the antibodies will not be damaged by short exposures to such a low $\mathrm{pH}$. Therefore the loss of activity is minimal in almost all antibodies with this isolation method, provided the eluates are quickly neutralized. Despite the shortcomings that have to be taken into account on some occasions, HPAC with a protein A column is a convenient method for preparative purification of antibodies. Whenever the antibodies bind to protein $A$ (or protein G), this isolation method is the first choice. If a citrate buffer is used for elution, the antibody solution can be used immediately after neutralization, e. g. for coupling to activated supports (2).

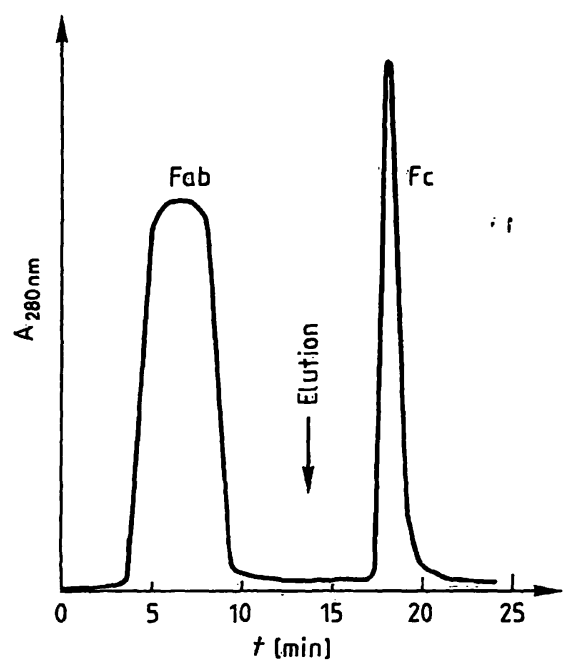

Fig. 6. Separation of Fab- and Fc-fragments from IgG. The isolated IgG was digested with papain (see 1.c. (21)). After digestion, the sample (the equivalent of $5 \mathrm{mg}$ of protein) was applied to a $60 \times 4.6 \mathrm{~mm}$ protein $A$ Eupergit $C 30 \mathrm{~N}$ column. The antigen-binding fragment (Fab) does not bind to the column. The Fc-fragment, however, became bound to the protein $A$ and could be eluted with $0.1 \mathrm{~mol} / \mathrm{l}$ sodium citrate buffer, pH 2.4 Conditions, $0.5 \mathrm{ml} / \mathrm{min}$ flow rate, $2-5$ bar pressure, room temperature.

Another example of the use of a protein A-HPAC column, for the separation of Fab- and Fc-fragments from an antibody, is shown in figure 6. After cleavage of the antibody with papain (cf. 1.c. (21)), the protein A-binding Fc-fragment can be retarded on the column, whereas the antigen-binding Fab-fragment is excluded. The separation shown here is very quick and simple, and the Fab-fragment is separated under very mild conditions. After elution of the Fc-fragment, e.g. at low $\mathrm{pH}$, the colum can be used again after a short equilibration period.

\section{Immunoaffinity HPLC}

The isolated antibodies can be covalently bound to activated supports, e.g. CNBr-sepharose, and used for immunoaffinity chromatography. Several activated supports are now available, which can also be used for HPLC. Figure 7 shows an example of immunoaffinity HPLC. The isolated monoclonal antibody against glycoprotein GP105, a membranebound antigen (5), was bound to activated silica and used for "one-step" isolation of the antigen from the plasma membrane extract. Although over 100 proteins were solubilized after membrane extraction with the non-ionic detergent Triton X-114 (7), the antigen was highly enriched in only one chromatographic step (cf. the electrophoretical represențation in fig. 7). 


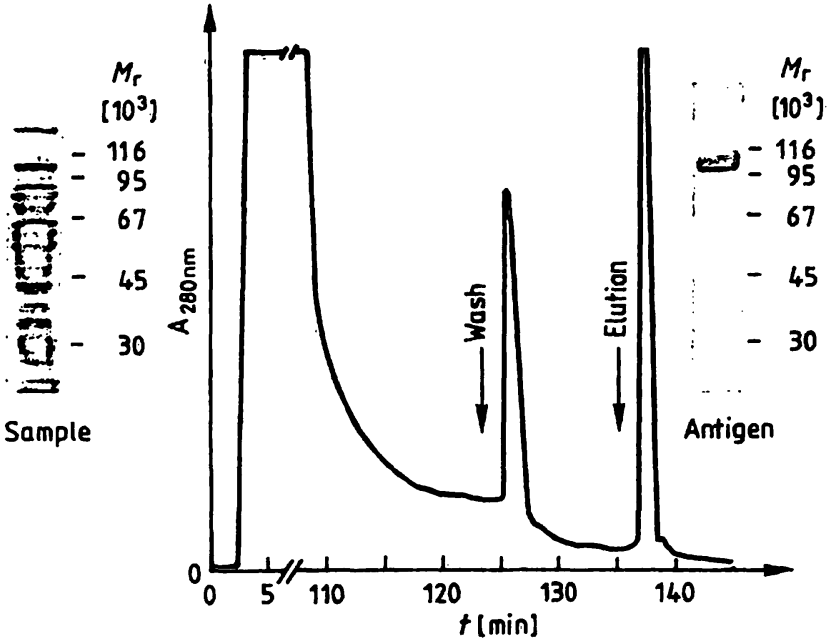

Fig. 7. Isolation of a glycoprotein (GP 105) from liver plasma membranes with immunoaffinity HPLC. A Triton $\mathbf{X}$ 114 extract, $50 \mathrm{ml}$, from liver plasma membranes $(80$ mg of protein) was applied to a column with immobilized monoclonal antibodies against GP 105. After washing of the column with $10 \mathrm{ml}$ of $0.1 \mathrm{~mol} / \mathrm{l}$ sodium borate with $1 \mathrm{~g} / 1$ Genapol X 100 ("wash"), the antigen could be eluted with $0.1 \mathrm{~mol} / 1$ sodium citrate, $\mathrm{pH} 2.4$, containing $1 \mathrm{~g} / \mathrm{l}$ CHAPS. Conditions, column - anti GP-105 IgG, bound to tresyl-activated silica (IgG 20 $\mathrm{mg} / \mathrm{g}$ support), $40 \times 4.6 \mathrm{~mm}, 1 \mathrm{ml} / \mathrm{min}$ flow rate, 20 bar pressure, temperature of $0^{\circ} \mathrm{C}$ (on ice). The composition of the applied sample ("sample") and the eluate ("antigen") was monitored by SDS-PAGE and shown in the chromatogram.

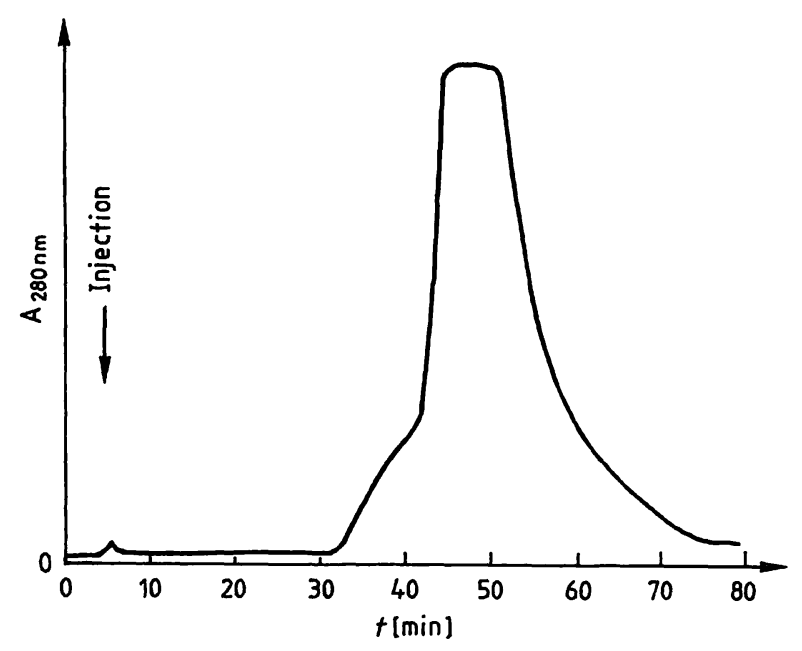

Fig. 8. "In situ" coupling of antibodies on a column packed with activated supports. A solution with a monoclonal antibody, $5 \mathrm{ml}$, was applied to a column with tresylactivated Eupergit $C 1 Z(1 \mu \mathrm{m}$ particle size). The antibody concentration was $3.2 \mathrm{~g} / \mathrm{l}$. Binding was monitored by measuring the absorbance at $280 \mathrm{~nm}$. When the $\mathrm{IgG}$ from the $3.6 \mathrm{ml}$ of solution was fully bound, an increase in absorption was observed. Subsequent protein determination in the fractions that did not bind to the column, showed that $5 \mathrm{mg}$ of antibodies failed to bind, whereas $11 \mathrm{mg}$ of antibodies bound to the column. Any free active groups were saturated by ethanolamine (see Materials and Methods). Reaction conditions: Column dimensions were $20 \times 4.6 \mathrm{~mm}, 0.1 \mathrm{ml} / \mathrm{min}$ flow rate, 8 bar pressure, room temperature.
The major disadvantage of the method shown above lies in the rather extreme conditions that have to be applied to isolate the antigens from the columns. In the experiment shown here, $0.1 \mathrm{~mol} / 1$ citrate buffer, $\mathrm{pH} 2.4$, was used, to which $1 \mathrm{~g} / 1$ of the detergent Genapol was added. Sometimes $3 \mathrm{~mol} / 1$ sodium thiocyanate or $6 \mathrm{~mol} / \mathrm{l}$ urea has to be applied to achieve elution. As a consequence of such treatment the immobilized IgG is quickly denatured, and the column loses its binding capacity for the antigen. The life of a column with immobilized antibodies averages 5 to 10 , at best 20 runs. Thereafter the capacity of the column decreases progressively, and non-specific binding increases. In order to avoid these disadvantages, Ohlson et al. (22) suggest the application of antibodies with low affinity to the antigen. When a column is packed with such antibodies, the less strongly bound antigen can be eluted under very mild conditions, e.g. simply by raising column temperatures. At $+4{ }^{\circ} \mathrm{C}$ the antigen binds to the antibody. At temperatures between 30 and $40^{\circ} \mathrm{C}$ it can be eluted by applying the same buffer or by slightly lowering the $\mathrm{pH}$, e.g. to 5.5 .
The immobilization of an antibody and the packing of a column is always time-consuming and expensive. Therefore the option of coupling the antibody "in situ" to a column already packed with an activated support is a suitable alternative. Figure 8 shows an example of such an "in situ" coupling. The antibody solution was pumped through a column that had been pre-packed with tresyl-activated silica, immediately after elution from a protein A column and adjustment of the $\mathrm{pH}$ to 7.2. It can be seen in figure 8 that the antibody from the first portion of solution $(3.6 \mathrm{ml})$, with an IgG concentration of $3.2 \mathrm{~g} / \mathrm{l}$, has bound to the support. After that a steep increase in absorbance takes place. It follows that a $20 \times 4.6 \mathrm{~mm}$ column, containing about $200 \mathrm{mg}$ of silica, has bound approximately $11 \mathrm{mg}$ of antibody. Such "in situ" immobilizations of different ligands have been described before $(2,22,23)$. The first commercially available columns, which are packed with an epoxy-activated support, are less effective because of the rather low reactivity of the epoxy groups. Meanwhile, newly developed activated supports are available, such as activated silica or porous and non-porous polymer 
matrices, which have been activated with tresyl- or other active groups $(3,24)$. Cartidges, pre-packed with the activated support, provide an even better alternative, as can be seen in the experiment shown in figure 8 . On the one hand, the high binding capacity of the material allows the immobilization of a sufficient quantity of immunoglobulin. On the other hand, the cartridge can be exchanged almost like a precolumn, when the above-mentioned short life makes the column useless. This is a much simpler and cheaper way than the exchange of an entire prepacked column. It must be pointed out, however, that other packings for short term usage are feasible, whose application has to be considered in relation to the particular problem that presents itself. An interesting example for the approach to a single problem is the packing of a small amount of material with immobilized antibody to the end of a slightly larger sample loop. The sample is then pumped through the loop with the antibody, where the antigen is retarded. This method, which was reported by Regnier et al. (25), can be very useful for analytical purposes, such as "mapping" of the epitope to an antigen that reacts with a particular monoclonal antibody.

\section{Indirect immunoaffinity HPLC}

Immunoaffinity HPLC, though being an elegant and quick method for analytical as well as preparative work, has the above-mentioned disadvantage of short column life, despite partly successful attempts to diminish its consequences. This applies above all to analytical work, where often large numbers of analyses have to be carried out in succession. As the antibodies, in the described method, are immobilized by covalent binding to free amino-groups, they will adhere to the support via different parts of the molecule, depending on where these groups are located in the polypeptide chains. If the interaction between the antigen and the antibody is disrupted, because the antibodies bind to the support with their antigenbinding site, the consequence is an impaired binding capacity of the antibodies. Ohlson et al. (22) found that the capacity of the bound antibodies had decreased to $55 \%$ of that of free immunoglobulin. Therefore Philips et al. (26) suggest that the antibody be first attached via the constant region of the immunoglobulin chain to a column with immobilized protein A. By cross-linking, the antibody is then in turn immobilized to the protein A. Thereby the binding capacity of the immunoglobulin is preserved, because the antigen-binding sites are free. The problems of the short column life still persist. Consequently we have not chosen the cross-linking of the immunoglobulins with the protein A. The principle of our method, which we call indirect immunoaffinity HPLC, is shown in figure 9. An appropriate amount of antiserum (or ascites fluid) is applied to a column with immobilized protein A. After washing the column with a buffer containing detergent, only the IgG is still bound, without any of the other proteins being non-specifically bound. The solution containing the antigen is applied to the column in a second step. Now the antigen binds to the antibodies, and the other proteins are excluded. After washing out the non-specifically bound material with buffer and detergent, the antigen-antibody-complex is eluted from the column (e.g. with a low pH buffer). This method can be used very successfully instead of immunoprecipitation, especially if the antigen is labelled radioactively, as shown in figure 9. The transferrin isolated from rat serum was radioactively labelled with $\left.{ }^{[35} \mathrm{S}\right]$ methionine. The left half of figure 9 shows the control of the eluate from the column by SDS-PAGE. By staining with Coomassie blue the antigen transferrin can be visualized, together with the light and heavy chain of the used antibody. If the same gel is autoradiographed, as shown in the right part of figure 9 , only the radioactively labelled antigen transferrin can be seen. In this way the half-lives of the ${ }^{35} \mathrm{~S}$ labelled methionine and the ${ }^{3} \mathrm{H}$-labelled sugar fucose in the rat transferrin could be measured quickly (27).

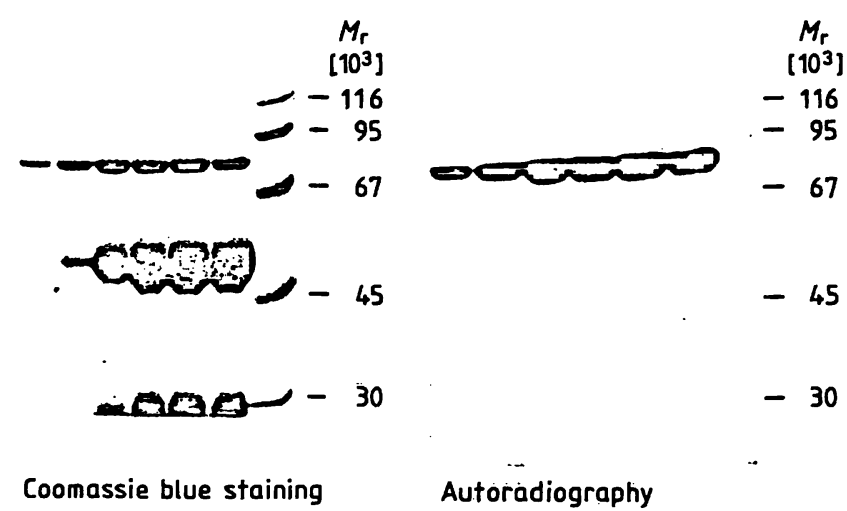

Fig. 9. Indirect immunoaffinity HPLC of serum transferrin with anti-transferrin antibodies, which are bound to a protein AHPAC column. Non-labelled rabbit antitransferrin antiserum was applied to a protein A-Eupergit $C 30 \mathrm{~N}$ column $(60 \times 4.6 \mathrm{~mm})$. In order to remove the non-specifically bound protein, the column was washed with $0.1 \mathrm{~mol} / \mathrm{l}$ sodium borate, $\mathrm{pH} 8.2$, with $1 \mathrm{~g} / 1$ Genapol X 100 . Subsequently the ${ }^{35} \mathrm{~S}$-labelled serum proteins were applied, from which the immunoglobulin had been removed by protein AHPAC. After washing with $0.1 \mathrm{~mol} / 1$ sodium borate, $1 \mathrm{~g} / \mathrm{l}$ Genapol $X 100$, the antibody-transferrin complex was eluted with $0.1 \mathrm{~mol} / \mathrm{l}$ sodium citrate buffer, $\mathrm{pH} 2.4$. The left part of the figure shows that the antigen (transferrin)-antibody complex was eluted from the column. Consequently both proteins were stained with Coomassie blue. As only the rat serum was labelled with $\left.{ }^{35} \mathrm{~S}\right] \mathrm{methionine}$, only transferrin with an apparent $M_{\mathrm{r}}$ of 78000 could be detected by autoradiography of the same gel i(see right part of figure). 


\section{Peptides}

\section{Chemistry $\cdot$ Biology $\cdot$ Interactions with Proteins}

Proceedings of the 50th Anniversary

Symposium of the Nobel Prize

Albert Szent Györgyi

August 31 - September 4, 1987, Szeged, Hungary

\section{Editors Botond Penke, Angela Török}

1988. $17 \mathrm{~cm} \times 24 \mathrm{~cm} . \mathrm{XX}, 467$ pages. With numerous illustrations. Hardcover. DM 275,-, approx. US \$ 157.00 ISBN 3110115468

Based on the presentation at an international meeting (the 50th Anniversary Symposium of the award of the Nobel Prize to Albert SzentGyörgyi), this volume compiles the knowledge accumulated in recent years, with new data on peptide synthesis, analysis and biology. The major objective of the book is to promote the interdisciplinary exchange of ideas and information between chemists, biochemists, physiologists and clinicians.

From the Contents:

In memoriam Albert Szent-Györgyi . Immunological Aspects of Peptides - Enzyme Substrates, Inhibitors and Toxins $\cdot$ Methods of Peptide Synthesis, Purification and Analysis - Molecular Mechanism of Hormone Action - Neuropeptides, Neurotransmitters and Behaviour - Peptides as Potential Drugs and Pharmaceuticals - Structure-Activity Relations - Structural and Conformational Considerations in the Design of Biologically Active Peptides - Participants - Authors' Index $\cdot$ Subject Index.

\section{Entzümadungug- diuggnessioly in der Laborroutine}

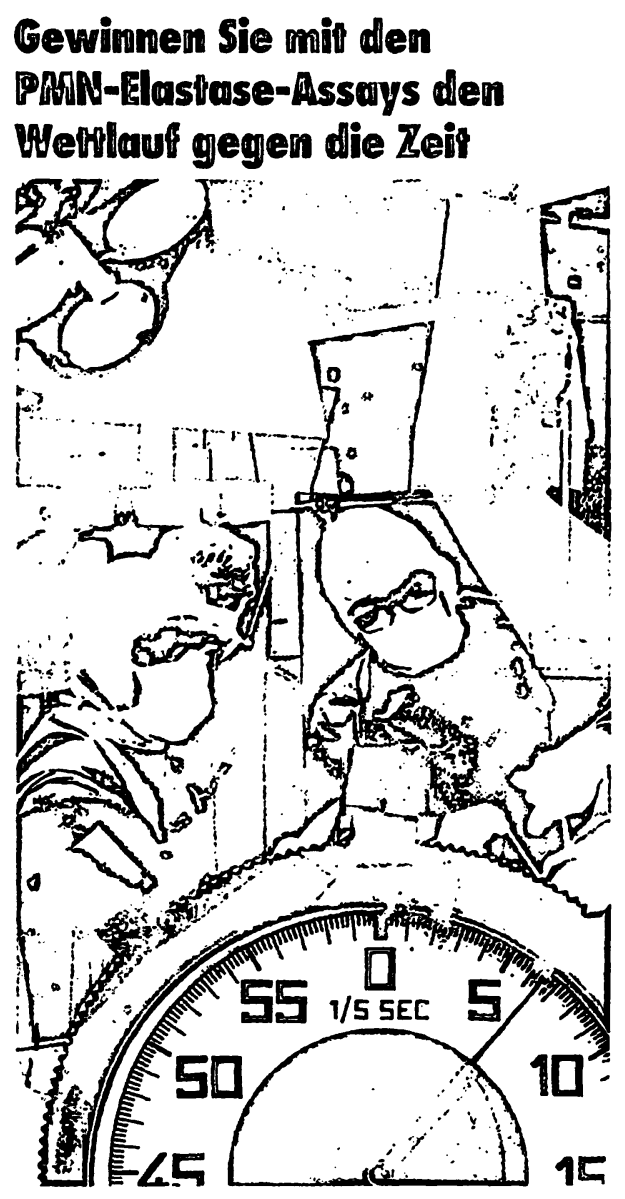

Die PMN-Elastase ist einer der sensitivsten Parameter zur Diagnose einer Entzündung. Die bekannte $2 \mathrm{~h}$-Version ermöglicht die Bestimmung aus Plasma, Stenalmark- und Synovialflüssigkeit und weiterem Untersuchungsmaterial. Ab Oktober 1988 steht der homogene Enzymimmunoassay PMN-Elastase IMAC zur Verfügung, er liefert aus dem Plasma innerhalb von 10 Minuten, bei manueller Methode innerhalb von 20 Minuten, die Entscheidungshilfe für den Kliniker.

\section{MERCIK}

E. Merck

Frankfurter Straße 250

D-6100 Darmstadt 1 


\section{Unconjugated Pterins and Related Biogemic Amines}

\section{Proceedings of the First International Workshop \\ Flims, Switzerland \\ February 28-March 7, 1987}

Editors H.-Ch. Curtius - N. Blau -R. A. Levine

$1987.17 \mathrm{~cm}$ x $24 \mathrm{~cm}$. XIV, 398 pages. Numerous illustrations.

Hardcover. DM 210,-; approx. US \$124.00 ISBN 3110113414

This volume contains a summary of the current advances in the field of pteridines and biogenic amines. Biochemical, analytical, immunological, and pediatric problems are the main themes discussed, but also interesting contributions from the fields of biogenic amines, chemistry, and medical applications of pteridines are presented. Each topic is introduced by a plenary lecture.

\section{Contents}

Synthesis of Pterins - Mass Spectrometry of Pterins · NMR of Tetrahydropterins - Purification of Enzymes Involved in Tetrahydrobiopterin Biosynthesis - Preparation of Monoclonal Antibodies Against Enzymes · Pterins in Different Diseases - Inborn Errors of Pterin Metabolism . Diagnosis and Treatment of Tetrahydrobiopterin Deficiency · Prenatal Diagnosis of Tetrahydrobiopterin Deficiency - Molecular Analysis of DHPR Deficiency - Tetrahydropterin Therapy in Neurological and Psychiatric Diseases · Monoamine Neurotransmitters and Enzymes.

Prices are subject to change without notice 
It is also possible to use several columns packed with different antibodies in tandem, and thereby bind different antigens from the antibody solution in a single run. Subsequent elution has to be performed separately. When indirect immunoaffinity HPLC is applied, it is important to bear in mind that in most cases the protein AHPAC column is not saturated with IgG. Consequently it can bind any immunoglobulin that may occur in the sample. This has to be given proper attention. The immunoglobulins have to be removed from the sample, e.g. by applying a protein A pre-column (without antibodies, cf. 1.c. (27)). The protein A columns required for these experiments - so far we have studied only two types, protein A-5PW and Eupergit $\mathrm{C} 30 \mathrm{~N}$ protein $\mathrm{A}$ - can stand up to 400 separations without any decrease in the binding capacity of the IgG.

It is well known that protein A does not bind all antibodies. Therefore two facts have to be established, before indirect immunoaffinity HPLC can be carried out. Firstly, the antibody, which is to be used, must bind to the column, and secondly, the antibody must not be washed out from the column by the applied detergents. If the antibody does not bind to the protein $A$, protein $G$ can be used. Protein $G$ binds several immunoglobulin sub-classes, which do not bind to protein A. Investigations concerning the application of protein $G$ as well as of other immunoglobulinbinding proteins, are presently being carried out in our laboratory.

\section{Conclusions}

The quickest and simplest method for the isolation of monoclonal and polyclonal antibodies is protein AHPAC. However, some monoclonal antibodies and certain polyclonal antibodies (e.g. from goat) do not bind to protein $A$. In these cases other isolation methods have to be applied. When new monoclonal antibodies are raised, it is therefore advisable to test their binding capacity to protein $\mathrm{A}$, and only those binding to protein $\mathrm{A}$ should be chosen. Their isolation is then easier, and their application to indirect immunoaffinity HPLC becomes feasible. A disadvantage of protein AHPAC is that the elution of the immunoglobulin requires rather extreme conditions, which can cause a loss of activity.

\section{References}

1. Köhler, G. \& Milstein, C. (1975) Nature (London) 256, 495-497.

2. Josić, Dj., Hofmann, W., Habermann, R., Becker, A. \& Reutter, W. (1987) J. Chromatogr. 397, 39-46.
If protein AHPAC cannot be used for the reasons mentioned above or otherwise, four alternative methods can be considered, namely hydroxylapatite, hydrophobic interaction, anion-exchange and "mixedbed" ion-exchange HPLC. In the case of monoclonal antibodies hydroxylapatite HPLC is quick and specific, whereas the isolation of polyclonal antibodies with this method requires an arduous optimization exercise. Anion-exchange HPLC has the advantage that columns can be used that are available in most laboratories for other purposes. Different antibodies will behave differently in such separations, and optimal conditions must be determined separately in every case.

The separation on a "mixed-bed" ion-exchange column is quick, simple, mild and also specific. It must be remembered, however, that final checks and optimization of this isolation method for any newly raised antibody are still necessary.

Hydrophobic interaction HPLC is a method, whose potential for the isolation of immunoglobulins has not yet been fully exploited. The experiments carried out so far have shown that this method is well suited for the isolation of monoclonal as well as polyclonal antibodies.

The isolated antibodies can be bound to different supports and used as highly specific ligands for immunoaffinity HPLC. The problem arising with these antibody columns is their short lifetime.

The application of the relatively stable protein $\mathrm{A}$ columns for the immobilization of immunoglobulins is one of the possible ways around the problem of the short lifetime of the antibody columns. After binding of the antigen the whole antigen-antibody-complex is eluted from the column, which can then be used for the next analysis. This method of indirect immunoaffinity HPLC can be used especially for analytical purposes, and it successfully replaces immunoprecipitation.

\section{Acknowledgement}

This work was supported by the Deutsche Forschungsgemeinschaft $(\operatorname{Re} 523 / 3-1)$, the Fonds der Chemischen Industrie and the Maria Sonnenfeld-Stiftung.

3. Ohlson, S. \& Wieslander, J. (1987) J. Chromatogr. 397, 207-212.

4. Hammen, R., Pang, D. C., Carlson, R. D. \& Judd, R. E. (1987) Proc. 7th Int. Symp. on HPLC of Proteins, Peptides and Polynucleotides, \# 514, Washington, D.C. 
5. Becker, A., Neumeier, R., Park, C.-S., Gossrau, R. \& Reutter, W. (1985) Eur. J. Cell Biol. 39, 417-423.

6. Tauber, R. \& Reutter, W. (1978) Eur. J. Biochem. 83, $37-45$.

7. Josić, Dj., Schütt, W., Neumeier, R. \& Reutter, W. (1985) FEBS Letters $177,182-186$.

8. Mans, R. J. \& Novelli, G. D. (1960) Biochem. Biophys. Res. Commun. 3, 540-543.

9. Bauer, C. H., Lukaschek, R. \& Reutter, W. (1974) Biochem. J. $142,221-230$.

10. Lowry, O. H., Rosenbrough, N. J., Farr, A. L. \& Randall, R. J. (1951) J. Biol. Chem. 193, 265-275.

11. Laenmli, U. K. (1970) Nature (London) 227, 680-685.

12. Bonner, W. U. \& Laskey, R. A. (1974) Eur. J. Biochem. 46, 83-88.

13. Matson, R. S., Clark, M., Dunn, L. C., Cummings, L., Ott, G. S. \& Siebert, C. (1986) Proc. 10th Int. Symp. Column Liq. Chrom., San Francisco, CA., 815a.

14. Josić, Dj., Schütt, W., van Renswoude, J. \& Reutter, W. (1986) J. Chromatogr. 353, 13-18.

15. Crane, L. J. (1987) In: Monoclonal Antibody Production Techniques and Applications (L. B. Schook, ed.) p. 139171, Marcel Dekker Inc., New York \& Basel.

16. Josić, Dj., Hofmann, W. \& Reutter, W. (1986) J. Chromatogr. $371,43-54$.
17. Juarez-Salinas, H., Ott, G. S., Chen, J.-C., Brooks, T. L. \& Tanker, L. H. (1986) Methods in Enzymology 121, 615622.

18. Josić, Dj., Hofmann, W. \& Reutter, W. (1988) Chromatographia, in press.

19. Björk, L. \& Kronvall, G. (1984) J. Immunol. 133, 969974.

20. Jürgens, D., Sterzik, B. \& Fehrenbach, F. J. (1987) J. Exp. Med. 165, 720-732.

21. Rousseaux, J., Rousseaux-Prevost, R. \& Bazin, H. (1986) Methods in Enzymology 121, 663-669.

22. Ohlson, S., Lundblad, A. \& Żopf, D. (1988) Anal. Biochem., in press.

23. Bülow, R. \& Overath, P. (1986) J. Biol. Chem: 261, 11918 11925.

24. Nielson, K. \& Mosbach, K. (1981) Biochem. Biophys. Res. Comm. 102, 449-457.

25. Regnier, F. E., Janis, L. J. (1987) Proc. 7th Int. Symp. HPLC of Proteins, Peptides and Polynucleotides, \#501, Washington, D.C.

26. Philips, T. M., More, N. S., Queen, W. D., Holohan, T. V., Kramer, N. C. \& Thompson, A. M. (1984) J. Chromatogr. $317,175-179$.

27. Josić, Dj., Tauber, R., Hofmann, W., Mauck, J. \& Reutter, W. (1987) J. Clin. Chem. Clin. Biochem. 25, 869-871.

Dr. Dj. Josić

Institut für Molekularbiologie und Biochemie

Freie Universität Berlin

D-1000 Berlin 33 (Dahlem)

West Germany 